\title{
FAMILIAL CREUTZFELDT-JAKOB DISEASE ASSOCIATED WITH A POINT MUTATION AT CODON 210 OF THE PRION PROTEIN GENE
}

\author{
Nancy Huang ${ }^{1}$, Suely K.N. Marie ${ }^{2}$, Fernando Kok², Ricardo Nitrini ${ }^{3}$
}

\begin{abstract}
Creutzfeldt-Jakob disease (CJD), the most known human prion disease, is usually sporadic but approximately $15 \%$ of the cases are familial. To date, seven CJD cases with codon 210 mutation (GTT to ATT) have been reported in the literature. We describe a case of a 57 year-old woman who presented gait disturbances and rapidly progressive dementia, leading to death four months after onset. Electroencephalogram revealed periodic activity, diffusion-weighted magnetic resonance imaging showed hypersignal in basal ganglia, and test for 14-3-3 protein was strongly positive in the CSF. The complete prion protein gene coding region was sequenced after PCR amplification, showing a point mutation in codon 210. This is the first case of CJD with codon 210 mutation diagnosed in Brazil. We emphasize the role of genetic search for prion protein gene mutation, even in patients presenting clinical features resembling sporadic CJD.
\end{abstract}

KEY WORDS: familial Creutzfeldt-Jakob disease, prion protein gene mutation, codon 210, 14-3-3 protein.

\begin{abstract}
Doença de Creutzfeldt-Jakob familial com mutação pontual no codon 210 do gene da proteína priônica
RESUMO - A doença de Creutzfeldt-Jakob (DCJ), a mais conhecida das doenças priônicas, é usualmente esporádica, mas cerca de $15 \%$ dos casos são familiais. Sete casos de DC] familial com mutação no codon 210 $(G T T \rightarrow A T T)$ foram relatados na literatura até o presente momento. Nós descrevemos o caso de uma mulher de 57 anos com distúrbios de marcha e demência rapidamente progressiva, evoluindo para óbito em 4 meses. Eletroencefalograma revelou atividade periódica, ressonância magnética com técnica de difusão mostrou hipersinal em gânglios da base e teste para proteína 14-3-3 no líquido cefalorraqueano foi fortemente positivo. A região codificadora do gene da proteína priônica foi sequenciada após a amplificação por PCR, revelando mutação de ponto no codon 210, constituindo-se no primeiro caso com esta mutação diagnosticado no Brasil. Enfatizamos a importância da investigação de mutações do gene da proteína priônica, mesmo em pacientes com quadro típico de DCJ esporádica.
\end{abstract}

PALAVRAS-CHAVE: doença de Creutzfeldt-Jakob familial, codon 210, gene da proteína priônica, mutação, proteína 14-3-3.

Creutzfeldt-Jakob disease (CJD) is the most well known human prion disease, a group of diseases related to the presence of the pathologic prion protein $(\operatorname{PrPsc})$ in brain tissue ${ }^{1}$. The incidence of $C J D$ is approximately 1 case per million inhabitants annually. The clinical picture includes a rapidly progressive dementia, myoclonus, and pyramidal, extrapyramidal or cerebellar syndromes². Electroencephalogram (EEG) may show periodic activity in approximately $65 \%$ of cases, with a specificity of $86 \%$. The presence of 14-3-3 protein in the cerebrospinal fluid (CSF), together with suggestive clinical features, has been considered highly sensitive and specific for diagnosis ${ }^{4,5}$. However, definitive diagnosis is still de- pendent on pathological confirmation of the presence of PrPsc in brain tissue.

About $15 \%$ of CJD cases are familial, associated with point mutations or insertions in the prion protein gene, which is located in the short arm of chromossome 20 . The clinical features and neuropathological findings tend to vary, depending on the different mutations. Codon 129 polymorphysms are also linked to CJD risk, clinical phenotype and prognosis $s^{6-8}$.

Our main objective is to report the first case of CJD associated with codon 210 mutation (V210I) diagnosed in Brazil. Data from this patient were previously reported emphasizing neuroimaging findings 9.

Behavioral and Cognitive Neurology Unit and Laboratory for Neurologic Investigations, Department of Neurology, Faculty of Medicine, University of São Paulo, São Paulo SP, Brazil: ${ }^{1}$ Post Graduate Student; ${ }^{2}$ Assistant Professor; ${ }^{3}$ Associate Professor.

Received 4 June 2001, received in final form 17 August 2001. Accepted 29 August 2001.

Dra. Nancy Huang - Rua Fernão Dias 279/14 - 05427-010 São Paulo SP - Brasil. 


\section{CASE}

A 57-year old woman, born in Germany and residing in Brazil, developed dizziness which was soon followed by gait and speech disturbances. A consultant neurologist detected a global cerebellar syndrome so requested laboratory tests and a brain CT-scan that on examination proved unremarkable. Her gait deteriorated and a rapidly progressive cognitive decline associated with myoclonic jerks became evident. A routine brain MRI was reported as normal. When she was first seen by us, two months after the onset of her symptoms, she was alert but unable to follow simple commands, with no eye-blinking to threatening stimuli, while reacting to painful stimuli by simply withdrawing the stimulated segment of body. She manifested spontaneous and startle myoclonus, increased tone with cogwheel rigidity in the arms, bilateral grasping reflex, and Babinski sign in the right foot. Routine blood tests and CSF analysis were within normal limits.

One of her sisters had died one year earlier, in Germany, with neuropathologically confirmed CJD. As far as we have been informed, no other members of the family have been affected by similar disease.

EEG revealed $1 \mathrm{~Hz}$ periodic sharp waves (Fig 1). MRI showed mild high signal in the striatum on $\mathrm{T2}$-weighted images, whereas diffusion-weighted MRI (DWI) showed high signal in the striatum, cortical areas of the insulas, left temporal lobe, and the borderland between frontal and parietal lobes, bilaterally.

The 14-3-3 protein immunoassay in CSF was performed as described by Zerr et al. ${ }^{10} .15 \mu \mathrm{l}$ of CSF were applied to Western Blot. Detection of the bound polyclonal antibody to the $\beta$-isoforms of the 14-3-3 protein (Santa Cruz Biotech, USA) was performed using the enhanced chemilumines-

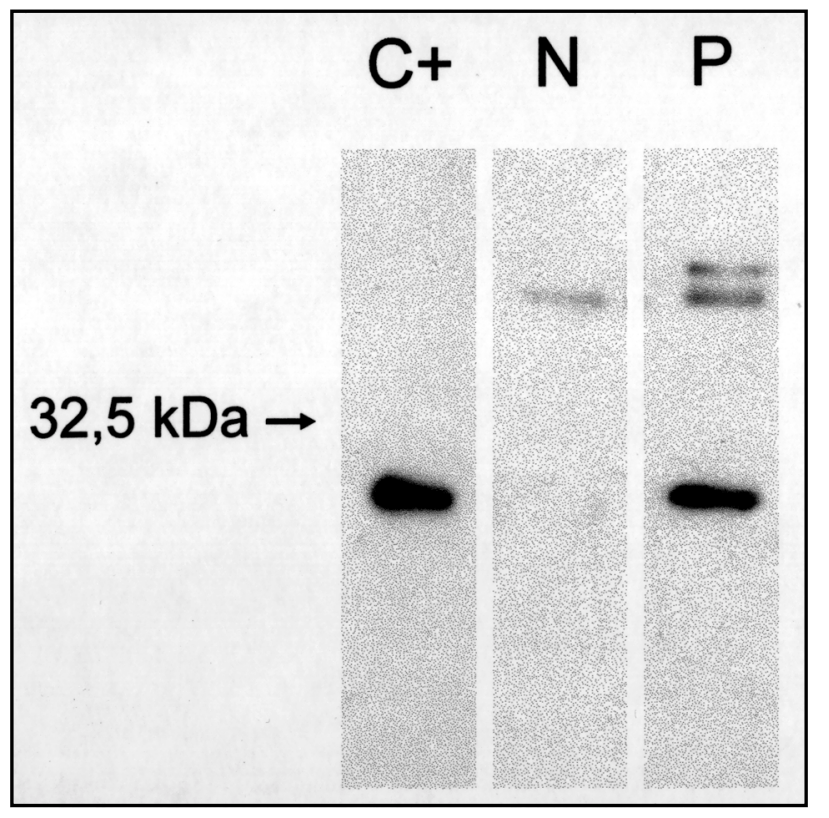

Fig 2. Immunoassay for 14-3-3 protein in CSF. CSF from patient with $\mathrm{V} 210$ I mutation (P) shows a band corresponding to 14-3-3 $\beta$ isoform. Positive control ( $\mathrm{C}+$ ); negative control (N).

cence detection kit (Amersham, USA). A positive control from the NIH3T3 cell line and a negative control were run on every gel. For this patient, 14-3-3 protein was positive in the CSF sample (Fig 2).

Genomic DNA was extracted from peripheral blood leukocytes by standard methods ${ }^{11}$ following the informed consent of family members. The complete PRNP coding region was sequenced by obtaining two frag-

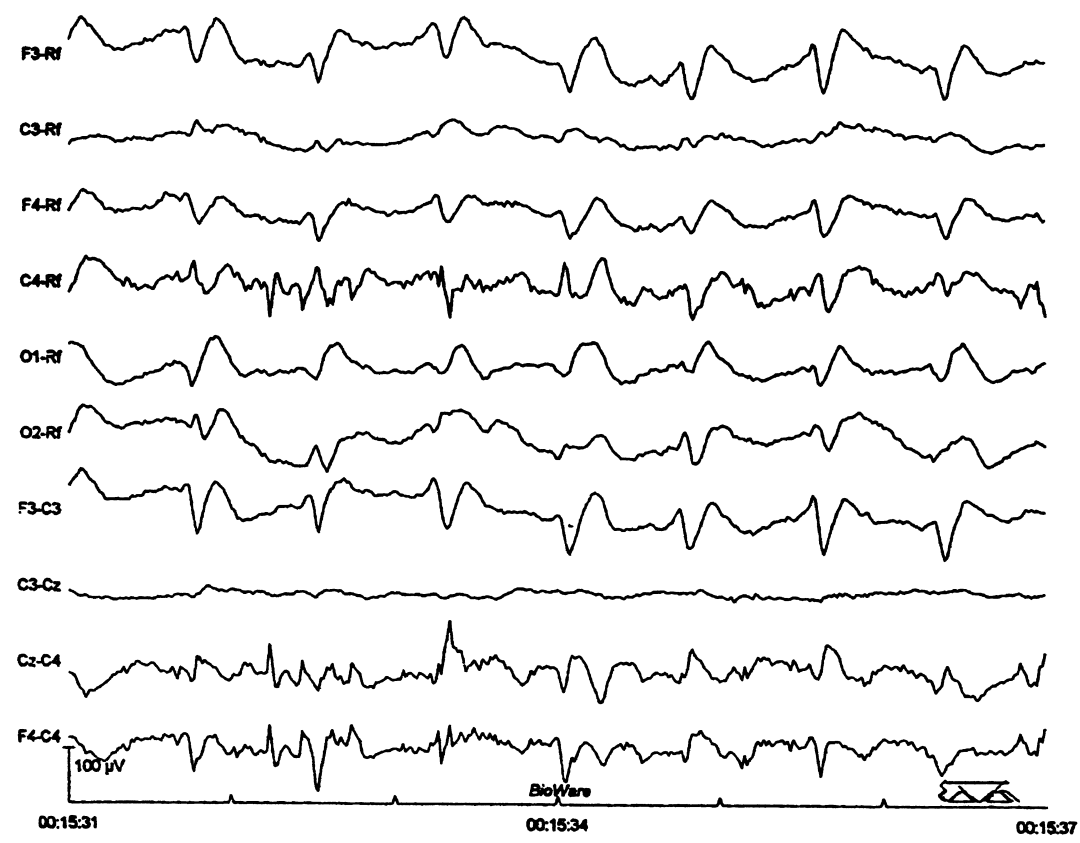

Fig 1. EEG showing periodic sharp waves at $1 \mathrm{~Hz}$. 


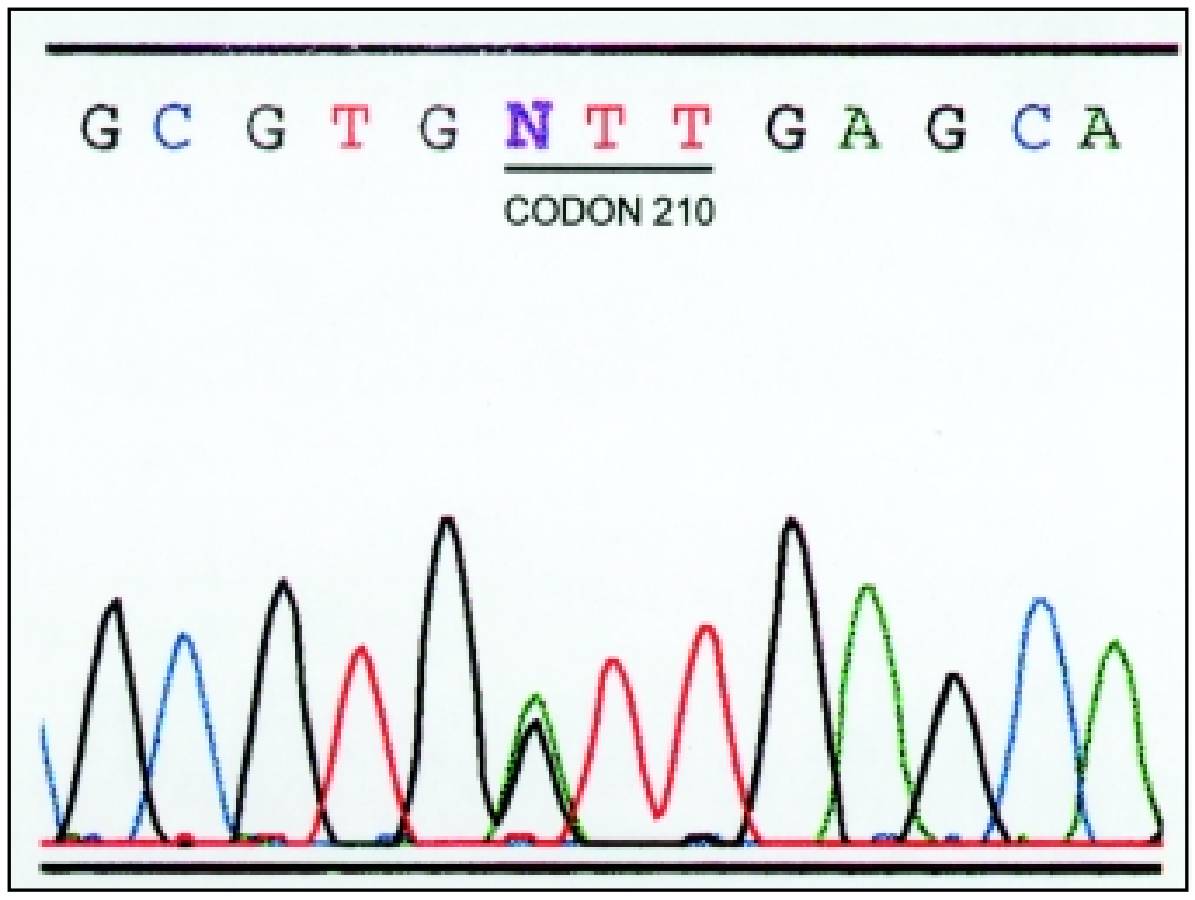

Fig 3. PRNP coding region sequence: letter " $\mathrm{N}$ " indicates a point mutation causing a substitution of valine by isoleucine in codon 210 (GTT-ATT). ments after PCR amplification. The fragment from open reading frame to codon 134 was amplified, using the pair of primers $F_{A}$ (5'-CTGACGTTCTCCTCTTCATTTG-3') and $\mathrm{R}_{\mathrm{A}}$ (5'-CTCATGGCACTTCCCAGCATGTA-3'). The cycle conditions were set ats $94^{\circ} \mathrm{C}$ for $30 \mathrm{sec}, 63^{\circ} \mathrm{C}$ for $30 \mathrm{sec}$, and $72^{\circ} \mathrm{C}$ for $1 \mathrm{~min}$. The PCR reactions were carried out for 30 cycles. The fragment from codon 107 to final of PRNP coding region was amplified, using the pair of primers $F_{B}$ (5'-AACCAACATGAAGCACATGG-3') and $\mathrm{R}_{\mathrm{B}}\left(5^{\prime}\right.$ TCCCTCAAGCTGGAAAAAGA-3'). The cycle conditions were set at $94^{\circ} \mathrm{C}$ for $30 \mathrm{sec}, 55^{\circ} \mathrm{C}$ for $30 \mathrm{sec}$ and $72^{\circ} \mathrm{C}$ for $1 \mathrm{~min}$. The PCR reactions were carried out for 35 cycles. We found a point mutation causing a substitution of valine by isoleucine in codon 210 (GTT-ATT) (Fig.3) and heterozigosity at codon 129 of the prion protein gene.

The patient died four months after onset of the symptoms. Autopsy was not performed.

\section{DISCUSSION}

Familial CJD associated with V210I mutation was first reported by Ripoll et al. ${ }^{12}$, and by Pochiari et al., in $1993^{13}$. Including these original cases, a total of 7 such cases with this mutation have been reported in the literature to date: one French patient ${ }^{12}$, one Italian family with two cases $^{13}$, one Japanese patient ${ }^{14}$, two Chinese cases from the same family ${ }^{15}$ and one individual from North Africa ${ }^{16}$.

The clinical and neuropathological features described in the Italian, French and Japanese patients were very similar to those of sporadic CJD with a rapid evolution to death (mean, 4.1 months) ${ }^{12-14}$.
However, the Italian case had a new 24-bp delection in the other allele ${ }^{13}$. One of the Chinese patients presented with panencephalitis at the age of 48 years, and the disease duration exceeded 24 months ${ }^{15}$. The patient from North Africa presented sensory symptoms as the first manifestation, a finding that is prominent in the new variant of CJD(nvCJD) ${ }^{17}$, and died 7.5 months after the onset of the disease ${ }^{16}$.

There have also been reports of individuals bearing V210l mutation who had remained asymptomatic at 72 and 82 years of age ${ }^{13,16}$, showing an incomplete penetrance.

Polymorphism at codon 129 is linked to both susceptibility to prion diseases, and to different clinical features ${ }^{8}$. For example, all nvCJD cases reported so far were homozygous for methionine at codon $129 \cdot 17$, and homozygosity at this codon is a predisposing risk factor to for sporadic and iatrogenic CJD. In different mutations of the prion protein gene, 129 polymorphism has been described as a factor that could modify survival time ${ }^{18}$. The influence of 129 polymorphism on 210 mutation phenotype has not been established ${ }^{8}$. Five out of the seven cases with the 210 mutation described to date, were methionine homozygous at the codon 12913-16. One of the Italian cases and the French patient did not undergo 129 polymorphism determination.

In the case we are reporting, apart from the heterozygosity at codon 129 , the clinical picture and evolution were typical of sporadic CJD associated 
with type 1 PrPsc and methionine homozygosity at codon 129 . This being characterized by a rapidly progressive dementia with myoclonus and periodic sharp waves on EEG ${ }^{19,20}$.

MRI in this patient showed the typical findings of high signal in basal ganglia and in a few cortical areas that have been described in CJD, and which are more evident in diffusion-weighted $\mathrm{MR}^{9,21}$.

Recently, 14-3-3 protein in the CSF was described as an important marker of $\mathrm{CJ}^{4}$. In this patient, the strong positive reaction of the 14-3-3 protein is possibly related to the rapid and progressive destruction of the brain tissue.

We emphasize the importance of genetic investigation to search for prion protein gene mutations, even in patients presenting typical clinical features resembling sporadic CJD.

\section{REFERENCES}

1. Prusiner SB. Prions (Nobel lecture). Proc Natl Acad Sci (USA) 1998;95:13363-83.

2. Brandel JP, Delasnerie-Lauprêtre N, Laplanche JL, et al. Diagnosis of Creutzfeldt-Jakob disease: effect of clinical criteria on incidence estimates. Neurology 2000;54:1095-1099.

3. Steinhoff BJ, Räker S, Herrendorf G, et al. Accuracy and reliability of periodic sharp wave complexes in Creutzfeldt-Jakob disease. Arch Neurol 1996;53:162-165.

4. Poser $\mathrm{S}$, Mollenhauer $\mathrm{B}, \mathrm{Kraubeta} \mathrm{A}$, et al. How to improvethe clinical diagnosis of Creutzfeldt-Jakob disease. Brain 1999;122:2345-2351.

5. Kenney K, Brechtel C, Takahashi $\mathrm{H}$, et al. An enzymelinked immunosorbent assay to quantify 14-3-3 proteins in the cerebrospinal fluid of suspected Creutzfeldt-Jakob disease patientes. Ann Neurol 2000;48:395-398.

6. Zerr I, Schulz-Schaeffer WJ, Poser S, et al. Current clinical diagnosis in Creutzfeldt-Jakob disease: identification of uncommon variants. Ann Neurol 2000;48:323-329.
7. Kovacs GG, Head MW, Bunn T, et al. Clinicopathological phenotype of codon 129 valine homozygote sporadic Creutzfeldt-Jakob disease. Neuropathol Appl Neurobiol 2000;26:463-472.

8. Mastrianni JA. The prion diseases: Creutzfeldt-Jakob, GerstmannSträussler-Scheinker, and related disorders.J Geriatr Psychiatry N eurol 1998;11:78-97.

9. Nitrini R, Mendonça RA, Huang N, et al. Diffusion-weighted MRI in two cases of familial Creutzfeldt-Jakob Disease. J Neurol Sci 2001; 184:163-167.

10. Zerr I, Bodemer M, Gefeller O, et al. Detection of 14-3-3 protein in the cerebrospinal fluid supports the diagnosis ofd Creutzfeldt-Jakob disease. Ann Neurol 1998;43:32-40.

11. Sambrook J, Fritsch EF, Maniatis T, et al. Molecular cloning: a laboratory manual, vol 2. 2.Ed. Cold Spring Harbor NY: Cold Spring Harbor Laboratory Press, 1989.

12. Ripoll L, Laplanche JL, Salzmann M, et al. A new point mutation in the prion protein gene at codon 210 in Creutzfeldt-Jakob disease. N eurology 1993;43:1934-1938.

13. Pocchiari $M$, Salvatore $M$, Cutruzella $F$ et al. A new point mutation of the prion protein gene in Creutzfeldt-Jakob disease. Ann Neurol 1993;34:802-807.

14. Furukawa $\mathrm{H}$, Kitamoto $\mathrm{T}$, Hashiguchi $\mathrm{H}$, et al. A Japanese case of Creutzfeldt-Jakob disease with a point mutation in the prion protein gene at codon 210. J N eurol Sci 1996;141:120-122.

15. Shyu W, H su Y, Kao M, et al. Panencephalitic Creutzfeldt-Jakob diseasein a Chinese family: unusual presentation with PrP codon 210 mutation and identification by PCR-SSCP. J Neurol Sci 1996;143:176-180.

16. Mouillet-Richard S, Teil C, Laplanche JL et al. Mutation at codon 210 (V210l) of the prion protein gene in a North African patient with Creutzfeldt-Jakob disease. J Neurol Sci 1999;168:141-144.

17. Will RG, Zeidler $M$, Stewart GE, et al. Diagnosis of new variant Creutzfeldt-Jakob disease. Ann Neurol 2000;47:575-582.

18. Baker HF, Poulter M, Crow TJ, et al. A minoacid polymorphism in human prion protein and age at death in inherited prion disease. Lancet 1991;337:1286.

19. Parchi P, Castellani R, Capellari S, et al. Molecular basis of phenotypic variability in sporadic Creutfeldt-Jakob Disease. Ann Neurol 1996; 39:767-778.

20. Parchi P, Giese A, Capellari S, et al. Classification of sporadic Creutzfeldt-Jakob disease based on molecular and phenotypic analysis of 300 subjects. Ann Neurol 1999;46:224-233.

21. Damaerel P, Heiner L, Robberecht W, et al. Diffusion-weighted MRI in sporadic Creutzfeldt-Jakob disease. Neurology 1999;52:205-208. 